\title{
The concept of entrepreneur of Schumpeter in comparison to Kirzner
}

\author{
Samuel Fernandes Lucena Vaz-Curado
}

Universidade Federal do Sergipe, Aracaju, SE, Brasil

\author{
Antony Mueller ${ }^{\mathrm{II}}$ \\ Universidade Federal do Sergipe, Aracaju, SE, Brasil
}

\begin{abstract}
This paper analyzes Schumpeter's concept of the entrepreneur in comparison to Kirzner and the Austrian School of Economics. For this purpose, the research uses the original German text as the reference, both the first larger edition of 1911 and the later shorter editions (mainly the seventh edition of 1987, which is an unaltered reprint of the fourth edition of 1934). To elaborate on the differences and similarities between Schumpeter and the Austrian approach, the study focuses on the aspects of equilibrium, discovery, speculation, capital, profit, institutions, and development. The analysis shows how the entrepreneur acts as the motor of economic development and how profit and profit expectations serve as the motifs of entrepreneurial action both for the pioneer of innovation and the imitators. Different from the Austrian School, Schumpeter applies the concept of equilibrium in the neoclassical sense as the starting point of his dynamic analysis. The Schumpeterian entrepreneur is that economic actor who breaks the statics to push the economy toward development, which is not merely economic growth because development signifies that fundamental changes of the economy take place in the process.
\end{abstract}

Keywords: Entrepreneurship, Schumpeter, Austrian School, Profit, Development.

DOI: https://doi.org/10.30800/mises.2019.v7.1

\footnotetext{
I Samuel Vaz-Curado holds a master's degree in Economics and is a leecturer of Economics at the Federal University of Sergipe (UFS). Email: samuelvazcurado@gmail.com

II Antony Mueller holds a doctorate in Economics from the University of Erlangen-Nuremberg of Germany (FAU) and is a professor of Economics at the Federal University of Sergipe (UFS). Email: antonymueller@gmail.com
} 


\section{O conceito de empreendedor de Schumpeter em comparação a Kirzner}

Resumo: Este artigo analisa o conceito de empreendedor de Schumpeter, em comparação a Kirzner e à Escola Austríaca de Economia. Para este propósito, a pesquisa usa o texto alemão original como referência, tanto a primeira edição maior de 1911, quanto as posteriores edições mais curtas (principalmente, a sétima edição de 1987, que é uma reedição inalterada da quarta edição de 1934). Para elaborar as diferenças e semelhanças entre Schumpeter e a abordagem austríaca, o estudo enfoca os aspectos de equilíbrio, descoberta, especulação, capital, lucro, instituições e desenvolvimento. A análise mostra como o empreendedor atua como o motor do desenvolvimento econômico e como o lucro e as expectativas de lucro servem como motivos da ação empreendedora - tanto para o pioneiro da inovação, quanto para os imitadores. Diferente da Escola Austríaca, Schumpeter aplica o conceito de equilíbrio no sentido neoclássico como ponto de partida de sua análise dinâmica. O empreendedor schumpeteriano é aquele ator econômico que rompe a estática para empurrar a economia ao desenvolvimento, que não é meramente crescimento porque significa que mudanças fundamentais da economia ocorrem no processo.

Palavras-chave: Empreendedorismo, Schumpeter, Escola Austríaca, Lucro, Desenvolvimento.

\section{El concepto de empresario de Schumpeter en comparación con Kirzner}

Resumen: Este artículo analiza el concepto del empresario Schumpeter en comparación con Kirzner y con la Escuela Austriaca de Economía. Para este propósito, la investigación utiliza el texto original en alemán como referencia, tanto la primera edición más grande de 1911 como las posteriores ediciones más cortas (principalmente la séptima edición de 1987, que es una reedición no modificada de la cuarta edición de 1934). Para profundizar en las diferencias y similitudes entre Schumpeter y el enfoque austriaco, el estudio se centra en los aspectos de equilibrio, descubrimiento, especulación, capital, ganancias, instituciones y desarrollo. El análisis muestra cómo actúa el empresario como motor del desarrollo económico y cómo las ganancias y las expectativas de ganancias sirven como motivos de acción empresarial, tanto para el pionero de la innovación como para los imitadores. A diferencia de la Escuela Austriaca, Schumpeter aplica el concepto de equilibrio en el sentido neoclásico como punto de partida de su análisis dinámico. El empresario schumpeteriano es el actor económico que rompe las reglas estáticas para impulsar la economía hacia el desarrollo, que no es simplemente el crecimiento económico, porque el desarrollo significa que en el proceso se producen cambios fundamentales de la economía.

Palabras clave: Emprendimiento, Schumpeter, Escuela Austriaca, Beneficio, Desarrollo. 


\section{Introduction}

The capitalist system depends fundamentally on the action of the entrepreneur. The entrepreneur is the figure who gives life to products and services that other people have not imagined. In two theories, the entrepreneur shows up prominently: in Schumpeter's theory of development, and in the Austrian School. In both, the entrepreneur is the one who moves the economy forward by creating new goods and services and new methods of production. Both approaches combine the pivotal role of the entrepreneur with the consumer sovereignty. For Schumpeter and the Austrians alike, the consumer is the final decision-maker. By deciding of what to buy or not to buy, the consumers decide over the fate of the entrepreneur.

Besides these obvious similarities, there are significant differences between the two approaches. In Schumpeter's model, the entrepreneur breaks with the usual functioning of the economy, rearranging the factors of production and creating a new order of production and consumption. In other words, the actions of the Schumpeterian entrepreneur provoke imbalances. In the Austrian model, in turn, entrepreneurial action coordinates the plans of other agents and keeps economic activity in a tendency towards equilibrium. In the Austrian perspective, the entrepreneur acts in an unbalanced situation, that is, a situation that causes him discomfort and, by acting, he expects to achieve greater satisfaction.

Schumpeter (1911) emphasizes that the neoclassical theory - of which he is a great admirer -, with its orientation on "equilibrium", only fits for a static economy, an economy that can change, but in such small steps that its basic characteristics would be retained over time. Yet modern economies are different. They are marked by a process which Schumpeter later (1942) called "creative destruction." Schumpeter's theory of economic development studies the source of the fundamental changes of this development, pointing to the constellation in which these transformations will appear and have a chance to persist and succeed.

The Austrian theory of the entrepreneur draws on the insights of Mises, Hayek, and Kirzner, and the modern contributors who have formulated a systematic Austrian model of entrepreneurship. While each author has a specific contribution to make, there are important points of agreement among the authors of the school. This article focuses primarily on Kirzner's approach to entrepreneurship. Nevertheless, there are gaps in his theory which will be filled in this article with the Austrian theory, considering that Kirzner built his theory on the contributions of his predecessors.

Despite the many advancements of the theory of entrepreneurship that have been made over the past decades, there is still a gap in the academic literature about the subject (KLEIN; BYLUND, 2014). The Schumpeterian model of innovation, in which seizing opportunities implies a process of disruption, is widely studied, including empirical investigations, while some of the Austrian approaches, as, for example, the Kirznerian model of discovery, remains still undervalued and suffers some neglect by the general entrepreneurship theory.

\section{Economic Equilibrium}

The prominent feature of the Austrian School is its radical individualistic-subjective approach to economic and social phenomena, both to macro issues, such as the business 
cycle, and to micro issues, such as entrepreneurship. The Austrian School rejects the formalmechanistic modeling inherent in neoclassical models in favor of a theory of human action based on subjective value judgments.

Based on the principles of human action, the Austrian School is not only modern in the methodological sense, but also modern in the choice of the objects of its research. As Mises (2009, p. 28) stated: "what distinguishes the Austrian School and will lend it everlasting fame is its doctrine of economic action, in contrast to one of economic equilibrium or nonaction". Unlike the schools of economics that study markets in a deterministic way in order to discover the characteristics of a point called "equilibrium," Austrian economists study markets as a process and dismiss "optimization" in favor of "human action".

In the Austrian perspective, error is an essential part of human action. Action takes place in time, is sequential, and changes the data as it takes place. The conditions of the future necessarily deviate from the past and are usually different from the expected results, because otherwise men would not continue to act. In this sense, current market prices are always "wrong". Otherwise, they would not change. Prices express expectations and therefore relate to the future. Equilibrium is irrelevant for human action and therefore for price changes. In the Austrian perspective, disequilibrium is the cause of human action. Dissatisfaction drives the human being to act.

The Austrian School of Economics rejects the idea of equilibrium as a static phenomenon because it argues that economic activity is inserted in time and the conditions that characterize a supposed equilibrium are constantly changing. Hayek (1937) shows that any market equilibrium analysis is based on data that change with economic activity. As agents interact with each other in the market process, they acquire knowledge that modify the conditions and data hitherto prevailing. The consequent alterations of the subjective views of the facts leads the agents to recalculate their actions, which makes a static equilibrium analysis impropriate for the understanding of the market process.

Austrians regard markets as dynamic processes, not static states of equilibrium. Markets may converge to an equilibrium, but they never reach this condition because economic activity and human action unfold over time and are determined under conditions of genuine uncertainty (IORIO, 2011).

The order brought about by competition is often called "equilibrium". Yet this is a misleading expression, since an actual equilibrium presupposes that the relevant facts have been discovered and that the process of competition has come to an end (HAYEK, 1968). Equilibrium can also be interpreted as a natural state of rest, which is pursued by all agents but can never be achieved given the scarcity of resources. In the natural state of rest, agents no longer need to act because they are totally satisfied because all their goals have been achieved (LACHMANN, 1978). To replace equilibrium, Hayek (1968) considers the concept of order. Particularly for economic policy discussions, "order" in place of "equilibrium" has the advantage that order can be realized to a greater or lesser extent and can be preserved over time.

For Mises, the market process is coordinative and ex post price coordination is the essence of the market. This means that the price system functions as a market clearing device. The equilibrium tendency, on the other hand, is an ex ante concept. It stresses the characteristics of the entrepreneur to anticipate and to eliminate maladjustments. Althoug these maladjustments 
show up continually, the entrepreneurial success in eliminating them would culminate in a state of optimum satisfaction (SALERNO, 1993).

Kirzner (1992) recognizes the continual characteristics of the market and points that it is never in a state of equilibrium. He adds that there are endogenous changes to the market that represent a tendency to equilibrate markets, though these are never completely fulfilled because exogenous changes disrupt these tendencies. Nevertheless, Kirzner argues that these endogenous tendencies are responsible for the allocative efficiency and growth potential of the markets.

Lachmann (1986), however, suggests that one cannot expect that the equilibrating forces of the market process prevail over the dis-equilibrating influences. For him, market processes are formed by both equilibrating and unbalancing forces, so that both require the same treatment. For Lachmann, the analytic attention must be directed at both: the balancing and the unbalancing factors of the market process.

In contrast to Mises and Hayek, Lachmann (1977) proposes the abandonment of the concept of market equilibrium. In his view, the market must be interpreted as a continuous process, in which the actors pursue several objectives and have divergent expectations. Thus, the market is a process without beginning or end, consisting of constant and unexpected changes.

The Austrian characterization of markets is opposed to the approach taken by Schumpeter and neoclassical economics in general. For the Austrian School, there is no economic activity without the consideration of time. All agents must carefully encompass the time factor in their decision making. Already for this reason, the economy is never fully in equilibrium. Any notion of equilibrium presupposes a state in which no changes in data happen. Analyses that focus on equilibrium, must disregard the fact that data changes as the economic agents do act.

The link between the Schumpeterian and the neoclassical model is complementary. In the preface to the Japanese edition of his "Theory of Economic Development" (originally 1911), Schumpeter (1987) marks the theories of Leon Walras and Karl Marx as the context of his approach. In Schumpeter's assessment, Walras's great contribution to economics was to establish the system of economic interdependence of quantitative economic variables in a purely logical way. As much as Schumpeter admires this grand feat, he also notes that the Walrasian system is incomplete. It is not only static, which anyone, including Walras himself, would admit, but, according to Schumpeter, also a system that can only be usefully applied to a "stationary process." In this regard, Schumpeter sees his contribution as an indispensable complement to Walras and thus as an effort to make the neoclassical theory complete.

In this same preface to the Japanese edition, Schumpeter (1987) explains that a "static theory" refers to the conditions of equilibrium and as such, the system returns to equilibrium after minor disturbances. Such a "stationary process" does not endogenously change but produces constant rates of real income increase over time. For Walras, and for the modern neoclassical economics, the theory of static equilibrium also encompasses the "stationary process". Schumpeter, by contrast, points out that static theory does not cover fully the working of the modern economy. In the economy, there is an additional force at work, a source of energy, which drives the capitalist economy on the path to development. 
Schumpeter's intention in his development theory is to provide a pure economic theory that complements the Walrasian model to cover aspects for which the neoclassical approach is insufficient. In this sense, Schumpeter sees himself as a theorist who takes up Karl Marx's project. Like Karl Marx, Schumpeter wants to establish a theory that shows how economic evolution emerges as a process that results from the economic system itself. In this respect, it can be said that just as Karl Marx tried to deliver the dynamic part to the classical static system, Schumpeter wants to deliver the dynamic complement to the neoclassical system.

In Schumpeter's original model (1911), there is neither a static nor a dynamic equilibrium. Evolution, in its innermost essence, is a disturbance of the existing state with no tendency to restore the former state. Dynamic economics does not develop through the organic restoration of equilibrium but is "inorganic" in the sense that the economy undergoes a redesign. There is no balance in place. In the organic world, rebalancing occurs as a reaction to the disturbance. In the economic development process, however, the disequilibrium itself is the driving force of the development. Development does not happen by itself but is the result of deliberate entrepreneurial action. Change does not simply happen but is caused, and Schumpeter identifies the entrepreneur as the author and the prime mover of economic development.

Schumpeter argues that entrepreneurship is associated with the process of "creative destruction," in which an exogenous innovation breaks with the state of the circular system. In this model, the innovative process of entrepreneurial activity implies the destruction of the equilibrium situation and the creation of new conditions. The entrepreneur is the figure whose innovative action destroys an established order and causes disequilibria (GIANTURCO, 2014).

For Schumpeter (1911), development and equilibrium are opposites that exclude each other. Dynamic economics should not be characterized by a dynamic equilibrium, as the steady state theorists suggest. In the Schumpeterian model, it makes no sense to deal with dynamic equilibrium, because equilibrium means statics. If the economy is dynamic, there can be no equilibrium. Equilibrium is exclusive to the profitless static economy. Only changing economies create unused opportunities and thereby profits. Therefore, the entrepreneur would have no function in the evenly rotating economy. Consequently, the entrepreneur is absent in conventional neoclassical static equilibrium economics.

\section{Entrepreneurial Discovery}

Despite their differences, both Austrian and Schumpeterian theory point out that there is no equilibrium in the market system. The causative agent of imbalances in both theories is the same: the entrepreneur. The Austrian entrepreneur prevents equilibrium in that he acts and is at the same time compelled to act because of his present dissatisfaction. The Schumpeterian entrepreneur, in turn, causes disequilibrium by introducing innovations in the market. These innovations that break the state of equilibrium occur persistently in a dynamic economy.

The economic theory of the Austrian School is inseparable from the concept of human action. Each individual has an ensemble of ends, ordered according to values subjectively attributed to them. In acting, the individual seeks to fulfill these goals and, to this purpose, uses the means at his disposal that he thinks are the most appropriate (MISES, 1998). To the means to be used, the individual orders them according to their subjective utility. Iorio (2011) 
explains that value and utility are two sides of the same coin. Utility is attributed to the means that the individual uses to act and achieve the ends, according to the value given to them.

The Austrian concept of the function of enterprise is directly related to human action. Business means the attempt to realize untapped profit opportunities. Thus, the concept of business constitutes a category of action. It highlights the capacities of each entrepreneurial individual to perceptive the opportunities and creatively pursue them. In this sense, Bostaph (2013) points out the difficulty to separate innovation from entrepreneurship since the latter entails the pursuit of profit opportunities, which presupposes creativity.

The environment in which human action takes place is characterized by genuine uncertainty. The future is uncertain and open to the creativity of the individuals and their entrepreneurial actions. By choosing and acting, the entrepreneur, or the agent who acts entrepreneurially, gives up some options in favor of others. The actions that the entrepreneur renounces from his subjective scale of value are the costs. By definition, the ends chosen must have a higher subjective value for the agent than those ends that were renounced. The difference between the value the agent assigns to his choices and the cost of his actions is profit. Thus, if there were no costs associated with the choices, the profit would coincide with the value (BUCHANAN, 1969).

In Kirzner's perspective, entrepreneurship is conceived as the discovery of opportunities to create and capture economic value. This discovery can also be understood as the identification or recognition of opportunities. There are also interpretations that consider entrepreneurship as the evaluation and exploitation of opportunities. Opportunities, then, are situations in which the entrepreneur introduces novelties, from products and services to production methods, in order to profit (KLEIN; BYLUND, 2014).

Entrepreneurship is about finding opportunities and taking advantage of them. Kirzner's approach involves sources of opportunity, that is, the way in which opportunities are discovered, evaluated and exploited. Despite Kirzner's treatment of the "pure entrepreneurial" opportunities as objective, his focus is not on the nature of the entrepreneurial success (KIRZNER, 2009), but on the opportunities as a device of the tendency of markets to clear (KLEIN; BYLUND, 2014). The opportunities of Kirzner's model are exogenously given. As the entrepreneur takes advantage of these arbitrage opportunities, he serves as an instrument for market clearing (KLEIN, 2008).

The entrepreneur is a figure which is distinguished by the ability to perceive opportunities. There are two ways to discover chances for profit: the first is related to fortuitous discovery, while the second is the result of motivated search, in which entrepreneurial research consists in recognizing opportunities (KLEIN; BYLUND, 2014). Opportunities exist in two forms: in Schumpeter's theory, opportunities are innovative, rare and out of equilibrium. In Kirzner's model, opportunities are less innovative, more common and fully or close to equilibrium (SHANE, 2003).

Schumpeterian opportunities come from the introduction of new information, arising exogenously due to changes in technological, political or social nature. Kirznerian opportunities, on the other hand, are treated as discoveries, in which the entrepreneur realizes errors or omissions made at some earlier points in the market process. In this sense, the opportunities are endogenous. 
Austrian economics stresses that the market process is inherently uncertain. This genuine uncertainty causes limitations of the pricing system and, consequently, of the efficient allocation of resources. The information provided by the pricing system is incomplete and therefore agents make suboptimal, often wrong, decisions. It falls into the entrepreneurial function to acknowledge these errors and to take advantage of them by exploiting the profit opportunities left by previous entrepreneurs. In this sense, entrepreneurial action implies a process of systematic arbitration (KIRZNER, 1973).

The "alertness" to which Kirzner refers can also be described as, on the one hand, the sensitivity to market information and, on the other, the ability to use them creatively. Thus, Kirznerian alertness implies a sense of mental openness to inconsistencies, asymmetries, and changes that may generate profit opportunities (KLEIN; BYLUND, 2014). The entrepreneur must not only be sensible in identifying opportunities, but he must also be on the alert to exploit them.

In Kirzner's model, the entrepreneur is a passive agent who, from his alertness, notices opportunities and takes advantage of them (KIRZNER, 1999). Data changes come about independently, and the entrepreneur notices them passively, benefiting from them. For Kirzner, the characteristics of an active and aggressive entrepreneur belong to the Schumpeterian model (GIANTURCO, 2014).

The conception of "entrepreneur passivity" in Kirzner's model is controversial within the Austrian School. For Austrian critics of Kirzner in general, entrepreneurship is an attribute of action and there is no entrepreneurship without action. Therefore, entrepreneurial action is by necessity active (GIANTURCO, 2014). Kirzner's alertness model includes discovery as merely a random and haphazard factor. He distinguishes between "search" and "discovery" to conclude that the entrepreneur discovers by chance. In other words, the Kirznerian "alertness" is a state and not an action. However, within the Austrian tradition, if intuition itself is already an action, transforming it in some way to operate it, means a new action. Thus, both are actions, and actions must be active.

Kirzner argues that there is no action prior to the moment when the opportunity arises in the sense of choosing to be alert. It is not a decision to be aware of opportunities, because it is not possible not to be alert. The active and aggressive characteristics, according to Schumpeter's model on entrepreneurship, are relevant only when taking a multiperiod consideration into account. Kirzner (1999, p. 11) abstracts from all other aspects of the real world to focus solely on the essential feature of entrepreneurship, in what he called "a single-period world without production and without uncertainty". Nevertheless, Gianturco (2014) ponders that the singleperiod analysis, used by Kirzner to develop his passive entrepreneur theory, doesn't exist.

By introducing uncertainty into his model, Kirzner aims to bring it closer to the real world. For Kirzner (1999, p. 11), the alertness in an essentially uncertain, undefined, multiperiod world requires the entrepreneur to be bold, self-confident, creative and able to innovate. Such characteristics point to "the intrinsically active character of the action" (GIANTURCO, 2014, p. 42). More than simply alert, entrepreneurship requires speculation and imagination - all of which imply activity.

For Kirzner, the core of entrepreneurship lies in arbitrage, in taking advantage of the difference between buy and sell prices. Arbitration does not require resources, but only the 
perception of the opportunity for profit. Such untapped opportunity is seized by buying and reselling. Initially, the entrepreneur does not need to own assets in order to be conscious and alert to profit possibilities (BOSTAPH, 2013).

A specific role of the entrepreneur relates to economic competition. Unlike in sports, the market process has no predefined rules. It is up to the individual entrepreneurs to perceive, before other competitors, the change in the market process and to take advantage of his earlier perception (KLEIN, 2008).

Another way of explaining the function of the entrepreneur is by taking the world as being in a state of disorder in which there is a multiplicity of goods with a multiplicity of uses of these goods (LACHMANN, 1986). In this world of disorder, goods are not automatically related to each other and have no original function. The same applies to capital. The capital structure exists only in the entrepreneur's imagination. Throughout this disorder of goods, products, and capital, the entrepreneur envisions a production structure that will be useful for putting a plan of his own making into practice. Lachmann (1978, p. 72) shows "how entrepreneurs form and dissolve capital combinations in response to the varying needs of changing situations, and how these capital combinations, embodied in plans, have to be regarded at each moment as the 'atoms' of the capital structure".

The entrepreneurial perception is unique in the sense that the other actors do not it in the same way. In this sense, the role of the entrepreneur is similar to that of an artist. In the clutter of an art studio, with paints, brushes, canvas etc., it is the artist who will put a plan into practice that he has conceived in his mind. Moreover, all material used is available to any other individual. There are no advantages or privileges associated with the business role. The entrepreneurial function is to imagine, in the multitude of heterogeneous capital goods, the best way to unite them into a useful production structure that can generate value. The entrepreneurial plan is what unites capital in a concrete representation that shows up as "(b) eer barrels and blast furnaces, harbor installations and hotel-room furniture" (LACHMANN, 1978, p. 25).

The concept of the role of the entrepreneur was developed by Schumpeter in his book “Theory of Economic Development" (1911). In the preface to the second edition (1926), Schumpeter (1987) explains that nothing solid could be said about modern economics without regarding the role of the entrepreneur, and, along with the entrepreneur, about the function of profit, capital, credit, interest rates, and business crises. As Schumpeter shows, these concepts form the basic conceptual elements of his development theory. In order to understand how economic development and economic crises happen, he points to the need of studying entrepreneurship, profit, capital, credit, and interest.

Schumpeter shortened his book in the second edition in an effort to emphasize his main points. He fully cut out the seventh chapter of the first edition. In this chapter, Schumpeter had placed his theory of development in the context of cultural sociology. To his dismay, this chapter attracted the most attention of the reviewers of his book and diverted attention away from his main concern in developing a theory of development. More than in the later versions, the first edition of Schumpeter's theory of development highlights the role of the entrepreneur as the agens movens of economic development. It can be argued that by simplifying his book in the second edition, many of the original ideas and bold expression have been left out. 
In Schumpeter's theory, innovation is different from invention or discovery. The inventor is not necessarily an innovator. Innovation is the realization of a business idea, and the Schumpeterian entrepreneur is its maker. The visionary has a dream, but until he puts these ideas to work, he is not an entrepreneur. The entrepreneur is the person who creates a company to realize his ideas. The new combinations which the entrepreneur creates, do not necessarily or even typically originate from the older forms, but arise alongside the old forms of production and distribution.

Entrepreneurial action, as Schumpeter defines it, is not just "finding" and benefiting from an opportunity, as is the case with Kirzner's concept of entrepreneurship. Kirzner's businessman has the specific characteristics of "alertness". Schumpeter's entrepreneur, by contrast, has a specific talent and the energy for leadership and possess the desire to push his business vision forward. As the concept of Weber (1949) of an ideal type, Schumpeter's entrepreneur is neither an inventor nor a technician or administrator. He is primarily a leader who has a specific way of looking at the world and who has the will and the ability to move on by himself and to overcome the resistances that confront him.

For Schumpeter, entrepreneurship is struggle. It is the battle of the new against the old, the most productive against the less productive, the new and better products against the old goods and services. Entrepreneurs are different from the common businessperson. While everyone in business calculates and has a business spirit and wants to move on, the regular businessperson, different from the ideal type of the entrepreneur, does not leave the common path. The common businesspersons do their best within the traditional choice of methods and products. They act within the bounds of the rational management of their business. The entrepreneur, however, is the one who breaks out of the routine business and explores new ways of doing business.

Schumpeter's ideal type of the entrepreneur is a person who acts and performs as his way of self-realization. This entrepreneur is not a mere visionary or dreamer. He may have a dream, a vision, and an idea, but beyond that there is realization. Therefore, thus Schumpeter (1987) explains, full-fledged entrepreneurs are rare. This specific combination between vision and action make it only very unlikely that the entrepreneurial talent will be hereditary.

However, Schumpeter (1942) has predicted a different future of capitalism. With time, the figure of the passionate entrepreneur responsible for innovations would be replaced by schemes of innovation embodied in the big companies. Innovations would not be realized based on a dream or a vision of an individual entrepreneur anymore but would be transformed into a routine process. Thus, big companies would create programs of research and development to make continuously marginal or small innovations and thus maintain their position in the market.

Schumpeter's forecast marks what one could call his second phase. Since innovations would become a routine process inside big companies, the individual entrepreneur would lose space. There is a diminished role for the passionate entrepreneur that explores new ventures and while an almost mechanical process of innovations is on the rise. 


\section{Speculation}

All entrepreneurial activity is directed towards an unknown future. Errors will occur and cannot be completely eliminated, no matter how elaborate or sophisticated the "predictive" tools are. In this sense, the entrepreneur's action is speculative, and this condition is the root of corporate profit and loss. Speculation implies the uncertainty of success or failure.

Economic agents operate in the context of a social environment of unexpected change where not only the future is unknown, but current price information is incomplete. In this environment, probability estimates are irrelevant due to the uniqueness of decisions (SHACKLE, 1949) and the heterogeneity of situations (LACHMANN, 1978).

For Mises (1998), the entrepreneur's role exists because the future cannot be predicted accurately. Among the three basic ways of dealing with the uncertainty of the future speculation, probability and engineering - speculation is the typical way for human action to deal with economic and financial affairs and the uncertainties of life in general.

Speculation is the basic mode of business judgment. If the future were always correctly foreseen, speculation would be unnecessary, and the future market structure could be precisely calculated. In this case, the entrepreneur would be unnecessary, because his function could be performed by engineers and mathematicians. Economics would be transformed into a predictive science, similar to physics or chemistry. Samuelson $(1965, \mathrm{p} .275)$ proclaimed that "a good scientist should be good at some kind of prediction. (...) Similarly, a good economist has good judgment about economic reality". Yet the pursuit of exact prediction and the establishment of simple rules lead the mathematical economist to idealizations and forms of modeling that represent economic problems as if they were probability events. In doing so, human action disappears, and the remaining model provides a distorted picture of the real problems that human beings face in society (ROTHBARD, 1962).

Adopting the ideals of mathematization, economics has been led into ignoring the role of entrepreneurial judgment. This orientation turned economics into a study of theoretical and imaginary worlds and prepared the path to interventionism for political ends. Economists formed by this model of thinking are not well prepared when it comes to making judgments about political issues and business problems. Surrounded by the abstractions of their models, they are led to assume mechanical statistical certainty and probabilities, while in the real world of business and politics the biggest challenge is the unexpected change (MISES, 1998).

From the entrepreneur's point of view, it is futile to base economic decisions on formulas. Human action in the economy must use relative prices as indicators to make plans, but the information and numbers that appear as prices, must be evaluated, compared, and ultimately related to the personal value system and one's individual knowledge of the circumstances of time and space. As Hayek (1945, p. 526) writes:

Fundamentally, in a system in which the knowledge of the relevant facts is dispersed among many people, prices can act to coordinate the separate actions of different people in the same way as subjective values help the individual to coordinate the parts of his plan. 
The same rudimentary information has several meanings for different people, especially its practical relevance. Prices do not replace judgment but are the tool for making judgments.

For the Austrian economist, the market process is an "indissoluble intertwinement of actions and reactions" (MISES, 1998, p. 330), based on a variety of subjective assessments and a huge variety of individual plans, which are not directly observable beyond the resulting price connections. This relative pricing structure, however, does not reflect agreement on valuations, but is the product of a discrepancy in value assignment. Prices, while conveying information, do not imply that they are correct or "efficient".

What is commonly referred to as "current prices" reflects past conditions, and past prices are of little value to entrepreneurial valuation. In the words of Mises (1998, p. 331):

The prices of the past do not influence the determination of future prices. It is, on the contrary, the anticipation of future prices that determines the state of prices of the complementary factors of production. The determination of prices has, as far as the mutual exchange ratios between various commodities are concerned, no direct causal relation whatever with the prices of the past. The allocation of the nonconvertible factors of production among the various branches of production and the amount of capital goods available for future production are historical magnitudes; in this regard the past is instrumental in shaping the course of future production and in affecting the prices of the future. But directly the prices of the factors of production are determined exclusively by the anticipation of future prices of the products.

Since future demand will differ from the present, the existing capital structure today is not adequate to meet future demand. To this end, only constant adaptation and new capital formation can guarantee that the production process will offer the flow of goods demanded by consumers. This is the genuine role of the entrepreneurial speculation.

In contrast to deterministic approaches, Austrian economics leads to a greater awareness of the real problem we face dealing with the unexpected. To this end, neither easily applicable rules nor historical studies, including econometrics, can serve as a secure basis for decision making (HOPPE, 2010). In situations like these, it is up to the entrepreneurial judgment that can be appealed.

Investment faces risks, in the sense of known random possibilities, and uncertainty, that is, unknown distributions of results (KNIGHT, 1921). From this perspective, the entrepreneur's role is to anticipate the unknown future demand and pricing structure. Therefore, the main function of the entrepreneur is to deal with uncertainty. Speculation is therefore inherent to any entrepreneurial activity.

In a market economy, there is no certainty about future prices. The status of wealth, which is attributed to a certain arrangement of capital goods by the market process, is always at stake. In the words of Lachmann (1977, p. 312): "In a world of unexpected change the maintenance of wealth is always problematical; and in the long run it may be said to be impossible". It is this perception of the changing nature of wealth that differentiates the Austrian approach in an elementary way from that of the preachers of stabilization.

Stabilizers and interventionists ignore something essential to human action: error. In a complex and dynamic environment where the future is unknown, the occurrence of errors - or disequilibria, when defined in terms of meeting expectations - is an integral part of human 
action. In this context, free markets receive their privileged status not only from the chimera of being perfect, but because they allow continuous adaptation, that is, the constant correction of errors, as they are identified by subjective evaluations.

Thus, as Mises points out (1998, p. 867):

The entrepreneurial idea that carries on and brings profit is precisely that idea which did not occur to the majority. It is not correct foresight as such that yields profits, but foresight better than that of the rest. The prize goes only to those dissenters who do not let them be misled by the errors accepted by the multitude. What makes profits emerge is the provision for future needs for which others have neglected to make adequate provision.

The fact that the future cannot be predicted, and that innovation is therefore an act of speculation reveals that the essence of economic progress is entrepreneurship. Thus, a comprehensive planning of the future cannot be rationally justified because of the lack of reliable and complete information. As Hayek (1968) explains, business competition is indispensable for economic progress because competition is the devise that promotes discovery.

Although business speculation is fundamental to the unfolding of the entrepreneur's role in Austrian theory, this concept is not recognized by Schumpeter. Speculation, for Austrians, has to do with uncertain future-oriented business action. The Austrian model argues that the result of human action cannot be anticipated by the agent, so one must be a speculator.

In the Schumpeterian model, the concept of speculation is generally related to the stock market. There is no explicit speculation component in the entrepreneur's innovation in the sense of errors that lead to economic slowdowns. The entrepreneur is not a speculator but an enthusiast who combines vision with passion and foresight with action (SCHUMPETER, 1987). The Schumpeterian entrepreneur does not speculate but acts almost blindly in the pursuance of his vision. He's a man with passion without second thoughts, i.e. an "all or nothing" type. Schumpeter's entrepreneur may win or may fail, yet he doesn't do that neither based on probability calculation nor on the recognition of uncertainty and therefore in a speculative way.

Schumpeter relates speculation to another agent of his market model, the capitalist. While acknowledging that the future is uncertain, Schumpeter does not see the speculative character of corporate action. Speculator invests his capital without knowing the return he will get. Different from the entrepreneur, the speculator evaluates many options before proceeding with an investment. In this sense, speculation "works almost exclusively with short-term loans that can be granted today and denied tomorrow" (SCHUMPETER, 1987, p. 204).

Credit is of utmost importance for innovation, so that the venture's risks are not borne by the innovative entrepreneur, but by those who own capital, such as bankers and capitalists in general. They lend to the entrepreneur, "betting" on his plan and glimpsing the high profits that the success of the venture can bring. Schumpeter's entrepreneurial innovation needs credit as its monetary complement (SCHUMPETER, 1939, p. 111). The capitalists deliver the funds to finance the innovations of the entrepreneurs.

The innovative entrepreneur depends on external funding. Financial institutions are essential to drive the innovation process forward. However, the scarcity of financial capital requires selectivity of innovations. Deciding which ventures will succeed depends not only on the consumer, but also on the financial markets to which the entrepreneur is subjected 
(FELIPE, 2017). Thus, the capitalist is a speculator as he decides to finance innovation without being sure that it will succeed. Therefore, speculation in the Schumpeterian framework refers to financing by banks and financial institutions, not to business action per se.

\section{Capital}

Capital and entrepreneurship play an essential role in the functioning of the modern economy. However, both are almost absent in the dominant version of modern macroeconomics. It is in Austrian economics that capital and entrepreneurship stand out. The attention given to capital in its relation to time is at the heart of Austrian macroeconomics.

Böhm-Bawerk (1884) forms the starting point for the Austrian theory of capital by highlighting the heterogeneity of capital as an ordered structure of production. Unfounded criticism of the Austrian theory of capital did not recognize this starting point and instead continued to use a concept of capital as if it were homogeneous and, as such, measurable.

The Austrian tradition does not treat capital as a homogeneous entity, but as a process that is ordered and structured by business plans and refers to heterogeneous production goods. The heterogeneity of capital implies that the structure of capital is constructed as combinations composed of complementary elements that are organized by an entrepreneurial view (LACHMANN, 1978). The logic of capital is the entrepreneur's view of organizing capital goods in a way that he considers appropriate to meet future demands.

Capital as heterogeneous represents a fundamentally different perspective compared to standard neoclassical modeling. Capital, unlike labor and land, has no objective physical dimension. Capital exists in the form of heterogeneous capital goods whose unified representation exists in the entrepreneur's expectations and imagination. The capital structure is the result of plans and is built withstanding uncertainty and costs such as time and money (O'DRISCOLL; $\underline{\text { RIZZO, 1985). }}$

Empirically, capital emerges as heterogeneous production goods, but as such they do not represent capital. In the economy, capital arises when these goods are combined in the context of an entrepreneurial plan and perceived as a production process. Capital goods become capital, it can be said, only after they are organized according to the logic of the production process. The heterogeneity of capital goods becomes only equity when these production goods are given a specific position in a production process that is ordered with the aim of achieving economic progress (LACHMANN, 1956).

A specific production good has no value in itself but is evaluated by business judgment as to the position it should occupy within the overall production process. This means that production goods with the same physical properties may have different functions depending on their position in the production process. Physically similar or apparently identical goods reach their specific value by their position within the production chain. This position is the result of the entrepreneurial plan guided by relative prices and the expectation regarding the future price of the product (MISES, 1998).

Entrepreneurial action requires the maintenance of the causal logic of production and the conscious application of time so that the product goes through the production process 
towards maturity. Production takes time and gaining productivity by widening the production structure entails sacrifice. The entrepreneur faces a trade-off, delaying immediate satisfaction and refraining from possible consumption now, to get more or better goods in the future. Even in a highly advanced economy, where all types of tools are readily available and there is a near-constant flow of new technologies, production will take time and happen in stages, according to the causal demands of the production structure (BÖHM-BAWERK, 1884).

For a specific good to go through the production steps takes time, and these steps will have different chronological durations. From an economic perspective, each phase represents a different and distinct stage of production, whose relevance comes from its position within the arrangement. The definite position that is attributed to a specific production good within the chain of production steps is the source of the value of that specific production good and is derived from the entrepreneurial judgment about future demand for the final product (LACHMANN, 1978).

Kirzner (1973), in dealing with pure entrepreneurship, states that the entrepreneur does not necessarily have any resources, but that monetary resources can be provided by the capitalist, similar to Schumpeter's model. The Kirznerian state of alert is not a specific resource. Kirzner separates the functions of ownership and entrepreneurship and states that the "pure entrepreneur" is a decision-maker who does not require capital to act (SALERNO, 2008). This view of Kirzner is widely criticized within the Austrian tradition itself. The human being is always endowed with something, even if it is only his own capacity (GIANTURCO, 2014). The entrepreneur may not have the means of production as fixed capital, but one possesses human capital.

The entrepreneur carries with him the historical baggage like all other human beings. Economic activity consists of a trial and error process in which agents gain experience. Of course, experience is inherent in the individual and implies a feature that puts him ahead of others, at least in a particular segment of the market.

This leads to the theory of knowledge as developed by the Austrian School. Hayek (1945) states that the dispersion of knowledge means that each individual has only a small portion of knowledge, yet that this portion puts him at an advantage over other individuals. The knowledge one possesses is best used when the individual himself uses it. The scientific knowledge is only a small part of the relevant knowledge. As Hayek (1945, p. 521-522) points, even more important is:

(...) the knowledge of the particular circumstances of time and space. It is with respect to this that practically every individual has some advantage over all others because he possesses unique information of which beneficial use might be made, but of which use can be made only if the decisions depending on it are left to him or are made with his active cooperation.

The notion of experience can be added to the concept of human capital. There are skills that belong to individuals and that have been acquired in different ways. These skills, acquired by experience, characterize one's human capital. Therefore, the entrepreneur possesses human capital, regardless of how he will perform his entrepreneurial function.

Despite these considerations on human capital, one may be never be too cautions when using this expression. As defined, capital is a stock of heterogeneous goods that are traded and 
priced in markets. Knowledge, on the other hand, cannot be capital because it does not have a purchase price. Klein (2014) explains that the market only exchanges and prices labor and it is not possible to decompose what is paid as wages from the returns on "human capital".

In addition to knowledge, which is inherent in human beings and cannot be set aside, the entrepreneur also needs capital. The business plan, to be implemented, requires a capital structure that can be used in favor of the entrepreneur. There is no business action without some form of capital.

Capital exists heterogeneously in various dispersed products. Lachmann (1986), for example, describes markets as inherently disorderly. This heterogeneity of capital comes to life only in the imagination and action of the entrepreneur. It is the entrepreneur who will create a structure from what he realized is possible by observing the availability of capital.

The given diversity of goods needs the entrepreneur to become capital. Similarly, the entrepreneur needs capital to put his plan into practice. Capital does not follow innovation innovation follows capital. This happened during the Industrial Revolution, when the large concentration of financial capital in London financed the period's innovation boom. This is also true today, with a large concentration of start-ups in California's Silicon Valley region, where venture capital is widely available.

In close similarity to Carl Menger's concept of capital, Schumpeter (1987, p. 173) defines capital as the sum of money and other means of payment available to entrepreneurs at any given time. Capital is the purchasing power that enables the entrepreneur to obtain the inputs that he needs to perform the new combination of inputs.

The Schumpeterian entrepreneur is neither capitalist nor risk bearer. As an entrepreneur, he usually uses credit to get the purchasing power to launch his project. The modern entrepreneur is not conceivable without the banker, who is not so much an intermediary of purchasing power, but all so a producer in this sense (SCHUMPETER, 1987, p. 117).

With regard to financing the innovations, savings play no fundamental role in Schumpeter's theory of development. For Schumpeter, innovations are funded by the capitalist credit to entrepreneurs. Economic development depends not only on material capital, as stressed by classical economics, but also on money as a stimulant for innovation. The availability of credit, in turn, depends on social expectations about the future of the economy and the behavior of entrepreneurs.

In the hands of the entrepreneur, "credit" means a transfer of purchasing power. The transfer of credit to entrepreneurs makes development possible. Economic development signifies a substantially different use of existing labor and land services as "the enforcement of new combinations by depriving labor and land services of their usual uses" (SCHUMPETER, 1987, p. 174). In this way, the access to loans allows the entrepreneur to gain purchasing power and obtain the factors of production before the new production begins. Without the credit function, entrepreneurship in the Schumpeterian sense would be impossible, as a developing economy must necessarily have a finance system that transfers purchasing power to entrepreneurs. Credit transfer to entrepreneurs enables economic development.

Conventional economic theory says that a high level of savings is important for creating capital. Yet for Schumpeter, the materials that the entrepreneur needs, do already exist. The 
entrepreneur uses existing materials and combines them into a new form. The invention of the conveyor belt by Henry Ford is an example of this process. Ford did not create more capital but reorganized the profit potential of a re-organization of the existing capital structure. The capitalist progress is based on entrepreneurial ideas and no other system beyond capitalism can create new idea with the same frequency and force as capitalism. Not only do new ideas thrive in capitalism, new ideas and their realization are also a necessity that capitalism can continue to exist.

Schumpeter highlights the importance of the financial system throughout his treatise. When it comes to economic development and economic growth, a system that enables high profits and has a financial system that is capable of financing ideas is needed. He who has new ideas need not necessarily be a person who has wealth. It takes a system where idea creators have access to capital and the financial system. In Schumpeter's view, the major problem of underdeveloped countries is not the lack of ideas, but their lack of financing, their lack of capital.

\section{Profit}

In a capitalist economy, the consumer is the "sovereign" of system. He's the one who commands the course of production as the final arbiter. Consumer preferences determine what is being produced and by whom. Profit and loss arise as a result of consumers' decisions to buy or not, and this decides who among entrepreneurs is best suited to satisfy the most urgent needs and wants.

The profit-driven businessman is the center of the capitalist system. The pursuit of profit obliges business to use the means of production in favor of the consumers. Ultimately, it is consumer decisions that determine which business owner will suffer a loss and who will enjoy a profit. Profit and loss are tools of consumer sovereignty (MISES, 1952).

In the business economy, profit shows when an investment was well made, while loss indicates the need to abandon or modify an investment. Those entrepreneurs who do not effectively fulfill consumer desires suffer loss and disappear from the market. The function of loss is to eliminate inefficient ventures in favor of those best able to meet consumer demands.

The business activity is to anticipate the future pricing structure. If all economic actors correctly anticipated the future, there would be no profit or loss and the prices of the economy would reflect the prices of the future correctly at all times. In economic reality, however, profits arise for the entrepreneurs who have better foreseen the future prices of commodities and factors of production than the competitors. The best-guessing entrepreneur can purchase the use of inputs at a price that does not yet reflect the future prices of the product that will be produced by combining these inputs. If the entrepreneur buys the factors of production at prices at which the cost level exceeds the sales revenue, he will incur economic loss. Profits and losses are constantly present in a market economy, because the economy is subject to change. In this perspective, the entrepreneur's role is to deal with change and the reward for making it successfully is profit.

An essential function of the entrepreneur is to remove mismatches in the economy. Business consists of making use of technologies that have not yet been fully used in favor of 
consumers. The entrepreneur also responds to data changes as a result of changing consumer demand. Business is not simply about increasing production through the accumulation of capital. It is also necessary to select, from the multiplicity of technological possibilities, those that best serve to satisfy the consumer (LACHMANN, 1977).

The entrepreneur is not the same as an innovator, inventor or administrator. The main business function is decision making. The economic problem is not just production, but production in such a way that it serves first and foremost the most urgent needs of consumers. In this sense, the entrepreneur is the director of the economy.

Profits and losses are not just the result of capital investment, but of ideas. Capital itself is a dead thing. The Marxist thesis that it is capital that "generates" profit has no substance. Profits result from good ideas and its business achievement. "Profit is a product of the mind, successful in anticipating the future state of the market. It is a spiritual and intellectual phenomenon" (MISES, 1952, p. 21).

Pure capitalism makes those entrepreneurs rich who employ capital the best they can for the satisfaction of the public. The wealth of a capitalist is the result of extraordinary profits, and these profits, in turn, are the result of extraordinary foresight and the use of capital for the benefit of the consumers. "Profits and losses are instruments whereby consumers turn production activities into the hands of those who are best suited to serve them" (MISES, 1952, p. 24).

Profits appear when the misallocations are corrected by the entrepreneurial action. The greater the mismatch, the greater the potential for profits. Similarly, profits disappear when these mismatches are removed. In the imaginary construction of the evenly rotating economy, there is neither profit nor loss. In a stationary economy, the amount of profits that a business owner enjoys is equal to the total amount of losses suffered by other businessmen. It is only in a progressing economy that the sum of all profits made in the economy is greater than the sum of all losses suffered.

In such an economy, capital per capita increases and this increase comes from savings. To accumulate wealth, the successful entrepreneur must reinvest his capital and the capitalist must save, that is, postpone his consumption. Turning a small business into a big business requires capital accumulation and, as such, savings and reinvestment of profits. The higher standard of capital allows the pursuit of previously unattainable projects. Business profit is the engine of economic progress and, at the same time, the result of economic advancement. Only in a progressing economy do profits arise (ROTHBARD, 1962).

The benefits of a higher capital standard, which comes with a growing economy, are not limited to savers and entrepreneurs. Rising marginal labor productivity increases wages. The benefits are widespread for landowners, owners of raw materials and for those entrepreneurs who integrate new capital into new production processes. In the end, however, everyone benefits from economic progress. While excess profits disappear when mismatches are removed, the increase in the quality of life of the consumers will remain.

The emergence of profit is a test to determine if the company operates efficiently and if its product is useful to satisfy the public tastes. Business loss results from lack of buyers and as such is a sign that the business owner must change his business performance. The loss 
forces the entrepreneur to initiate performance changes or his company will disappear from the market. It is the remarkable sign of capitalism that under this system only the companies that best serve customers do prosper (ROTHBARD, 1962).

In the market, consumer decisions form a referendum. By buying or not buying, consumers determine who actually owns the factors of production. In a market economy, the actual owner of capital is the consumer. Consumer choices are experimental, and the market process takes the form of permanent experiences in which consumers constantly review their previous decisions and formulate new desires. However, neither entrepreneurs nor consumers are perfect. Thus, what distinguishes the market economy from the other forms of economic organization is its inherent ability to correct mistakes and innovate.

Poverty in backward countries results from the lack of entrepreneurs and freedom $(\underline{\mathrm{SOTO}}, 2010)$. In contrast, the standard of living of the masses is the highest in countries with the largest number of wealthy entrepreneurs. It is in everyone's interest that the factors of production - capital, labor and technology - are kept under the control of those who know how to best use them.

The Schumpeterian theory is very similar to the Austrian analysis of profit. For Schumpeter (1987), the essence of business profit is the result of the successful realization of the new combination of existing productive factors. Profit comes as a result of the new use of existing productive goods.

Once the pioneer has succeeded, he automatically gets followers and imitators, and the new industry becomes a new cluster, where innovation changes, but different from the pioneer, now in small steps and within a group of companies (SCHUMPETER, 1987). While the first to innovate may make excessive profits as the pioneer, profit opportunities are reduced among followers and imitators until they finally peter out, reaching the normal level of profit in the economy with the occasional little extra profits that the modifiers of existing products can earn. Imitation equalizes the profits and distributes the benefits to the consumers.

Extra profits may come from reorganizing the production or sales process, for example, or from product innovations. The extra profit of the pioneer is an essential feature of the process, because otherwise followers and imitators would not appear. The pioneer is a winner who by his victory also wins for his followers and imitators (SCHUMPETER, 1987, p. 213).

The pioneer entrepreneur, in the Schumpeterian sense, is the one who first realizes the greater value of the new combination compared to the current way of combining the productive elements. The pioneering entrepreneur realizes the discrepancy between the existing costs of current use of productive factors and the highest price he can obtain for his new combination (SCHUMPETER, 1987, p. 212).

The entrepreneur's specific contribution is not an invention or management or savings, but "will and action" (Wille und Tat) (SCHUMPETER, 1987, p. 216). The Schumpeterian entrepreneur does not create new means of production or accumulate goods or apply his savings. He uses existing means of production differently: more effectively, more productively, more purposefully, and more advantageously. The reward for doing this successfully defines his profit. 


\section{Institutions}

For the capitalist system to work properly, free access to markets by new companies and new entrepreneurs is indispensable. Not monopoly is the problem, but the market access. Government interference in the form of regulations and norms hinders market efficiency. Like any other economic system, the market economy is not perfect and capitalist production cannot fulfill every person's wants or needs. The market system also does not eliminate scarcity for all, but it is the economic order that best deals with the universal presence of scarcity.

Regulation on the grounds of consumer protection stalls economic progress and makes it more difficult to set up more efficient forms of business. In its extreme cases, state regulation completely blocks economic evolution and produces economic stagnation and decline (ROTHBARD, 1970).

It is a mistake to assume that business is simply management and production. Mere routine does not drive the economy, but economic progress needs business forecasting. The entrepreneur is the one who allocates capital where the most urgent needs arise every moment. The wealth level of a country is mainly the result of free enterprise. In poor countries, workers often work hard, but their income remains low due to the absence of free entrepreneurship (SOTO, 2010).

The wrong definition of profits can cause disincentives to business activity and ultimately delay the development of society. There is no such thing as a "normal profit." To the extent that there are no criteria for establishing "normal profits", there is no basis for condemning "excessive profits". Taxation based on the charge of "excessive profits" actually means punishing a company's success in better serving the public. Thus, taxation drives economic activity in the direction of waste and bad investment. When profit is vilified, tax policy moves the economy toward more costs and less efficiency.

Mises (1952) denounces the distinction between "deserved" and "undeserved" income as a result of envy. This unjustified differentiation forms the basis for variations in tax rates. Prejudice and lack of economic knowledge on the part of the public spill over into the tax laws. Confiscating the surplus of a company's economic activity implies a misappropriation of the control of capital from those who may best employ it in favor of public satisfaction for state power. In this way, political interests gain dominance over the use of scarce resources. These policies weaken the consumer's decision about the course of production. In addition to taxation, price inflation falsifies and hinders business calculation. In an inflationary environment, illusory profits emerge. This inflationary profit leads to wrong investments and higher tax burdens.

Public policies against corporate profit are the result of a misunderstanding of how markets work. These policies result from the assumption that companies have power and that they will abuse that power. The general prejudice against business merges with the aversion to the size of certain companies and, along with envy, form the emotional basis of the attack on profit. Politicians do not realize that it is the pursuit of profit that compels the entrepreneur to invest his capital in favor of consumers and supply products more efficiently (MISES, 1998).

Specialization is the key to prosperity and requires the division of labor. This is the main thesis of Adam Smith in his work "The Wealth of Nations" of 1776. The division of labor needs the market price system, which in turn requires money. The causal logic of Smith's theory is 
that prosperity requires productivity and that productivity results from specialization, which in turn requires the division of labor. This division of labor system needs prices, markets, and money to operate.

Unfortunately, Adam Smith's important insight into specialization and division of labor has been corrupted by some serious errors. In his "Wealth of Nations", Smith (2007) deals almost exclusively with the division of labor and ignores that the division of capital is just as important. Indeed, an important factor of economic progress comes from the specialization of capital. This way, Adam Smith ignored the fundamental role of companies in the modern economy as places where entrepreneurs combine work and capital.

In addition to ignoring the role of capital and of the entrepreneur, the way how Adam Smith elaborates his theory of value contains serious flaws. As Rothbard (2006) observed, Smith retreated from the theory of price and subjective value and led economic theory to a dead end, from which it took a century to recover and, in some respects, never fully recovered. It was mainly the Austrian School of Economics that elaborated on Smith's neglected aspects and corrected the errors of the Classical School of Economics. It was first of all the subjectivist and marginalist revolution initiated by Carl Menger, which was continued by Mises and Hayek, that advanced the thinking about the function of prices in the economy.

With the division of labor arises the problem of coordination. Small group coordination can be achieved by negotiation, and through tradition and personal contact. However, for the economy to grow out of the primitive state, new forms of coordination must be found. Historically, along with market relations, coordination by command has emerged, as is the case with war economies, slavery, and socialism (OPPENHEIMER, 1922).

For development and increased productivity, the division of labor and capital confronts the problem of coordination, both at a specific point of time and place, and for its intertemporal, regional, and global structure. Coordination by command is unable to fulfill this task. For complex interactions, society needs a price system to coordinate the economic activities. In the market economy, prices arise through the individual valuations based on subjective preferences. The emerging market process is both competitive and cooperative.

In his article originally published in 1920 in German, Mises (2012) shows that the problem of coordinating a modern economy cannot be solved without private ownership of capital goods. This thesis is based on Carl Menger's explanation that the value of capital goods represents an imputed value. In his prime work of 1871, his Principles of Economics, Menger (1985) argues that the value of a consumer good is determined by subjective assessment. Similarly, the value of investment goods is the result of their contribution to a consumer good, which receives its value from the subjective assessment of the consumer. It is only through trade in the market that prices emerge and become visible to all participants.

The economy becomes more complex as the division of labor and capital increases. This requires more autonomy for private property and freer markets. As the economy grows and becomes more complex, more capitalism will be needed. Mises (2012) lucidly identified the erosion of the institution of private property as the fundamental factor of socialism's economic failure and highlighted free markets as the path to prosperity. 
Hayek (1937; 1945) strongly emphasizes the role of prices as an information system that enables economic action without the need for complete knowledge of circumstances. The role of prices as an information tool becomes more important as the complexity of the economy rises. The greater the complexity of the economy, the more difficult it will be for a central agency to obtain and interpret relevant information and implement appropriate decisions. Private property, the market, and the price system are thus indispensable for the economic coordination as complexity grows. Because economic development means higher complexity, there will be no development without a market-based price system and private property.

Although the price system is not perfect, the private property-based market economy represents the system that best ensures efficient resource allocation and promotes productivity. Prices allow the expression of exchange ratios in a single number. This makes the cost of individual goods comparable to each other and allows one to compare costs with his own budget. Economic agents subjectively relate the price of good " $\mathrm{A}$ " to the price of good " $\mathrm{B}$ " in terms of the size of a budget, i.e. their income. Without money, prices could not exist; and prices would not exist if there were no private property, which is essential for exercising subjective valuation.

Coordination of activities in a complex economy requires private ownership so that market prices accurately reflect scarcity. Money prices convey information about relative scarcity and likewise provide the incentive to act on signals. Pricing allows the economic agents to adapt to a structure that may not be fully known.

In Hayek's approach, the function of the price system is not to inform about the past - as the equilibrium models of modern microeconomics imply - but to provide signals on what to do in the future. The price system gives signals that inform economic actors about the economic reality. In a free economy, the price system indicates how economic actors should dynamically adapt their behavior to meet the challenge of scarcity.

The abolition of the price system, as it takes place in a socialist economy, would destroy the coordination among the economic agents. The division of labor would cease to exist, productivity would fall, and society would descend into poverty. Nevertheless, the erosion of money and prices occurs every day, to a greater or lesser extent, through government interventionism. In addition to direct market interventions, price functioning is also hampered by the multitude of authoritarian laws of control and regulation.

Under the regime of the interventionist welfare state, private property and prices are subject to manipulation and these interventions distort the signals about the relative scarcities. Under the burden of interventionism, the economies suffer from malinvestments, lack of coordination, financial bubbles and disastrous recessions. Similarly, in modern monetary arrangements, which keep the money supply in the hands of government authorities, private economic actors are exposed to a constant threat of inflation.

From Schumpeter's point of view, companies are the main institutions of capitalism. When we look at any society in the world and compare it today with a hundred years ago, the striking difference is the role of companies. These modern firms exist in the market within a system of competition, not only of prices but even more so in a competition of innovation. Without innovation, companies do not only earn superior profits, they are also left behind by those firms which do innovate. 
Schumpeter maintains that extraordinary profits are essential for the market system to function. But extra profits cannot be maintained for long time in a competitive economic system. Profitability is essential for the system to work, but high profitability will exist only temporarily, because other companies mimic the innovative company or come up with new products and the old ones must disappear or recede. Capitalism is destructive of the old and benevolent to the new. Under free capitalism, there is no way to maintain wealth in a passive way. Because of the relentless process of innovation, individual wealth positions are not lasting. ${ }^{1}$

Economic progress through creative destruction involves losses. Yet this trade-off is marginally advantageous because only when the new method is more productive or if the product is better, the consumers will buy. Schumpeter - very similar to Mises - affirms that in the end, the consumer as the sovereign who decides. If an entrepreneur launches a new product that finds no buyers, the firm will fail. If an entrepreneur starts a new production method that is no longer productive, he will not be competitive. Economic progress consists of new and better products and more productive manufacturing methods.

Schumpeter $(1987$, p. 129) stresses that entrepreneurial action is not an easy task. Innovation meets resistances of many kinds. There are legal obstacles that confront new ventures, social resistance that does not like change, and probably most of all, "the energy-saving function of solid thinking habits." Resistance is particularly strong when the innovation does not only make marginal improvement through small changes and mild adaptations, but when innovations amount to breakthroughs. This type of entrepreneurial action exceeds the scope of the Kirznerian entrepreneurial alertness.

Schumpeter's entrepreneur is a person of vision and will. He is of supreme energy and goes against the prevailing habits of thought, against the lethargy of the masses and challenges the privileges of those who are currently in the positions of wealth and power. These fight back because, parallel to the ascension process of the capitalist world, there is a process of decline, declassification and the elimination of the old classes (SCHUMPETER, 1987, p. 369). In many ways, these obstacles that come from the old classes, still do exist in the modern world and try to block the new rich because the established owners of wealth want to keep their privileges.

The capitalist machine works to create and invent new consumer goods, new markets and new methods of production. In Schumpeter's view, these innovations appear apparently in a spontaneous way and abruptly. These innovations happen not continuously but in a cyclical fashion. The monopoly of the innovative pioneer is temporary. An innovation that shows its success attracts imitators and leads to a cluster of firms linked to the breakthrough.

There is no progress in development without costs, notes Schumpeter (1911, p. 493). The emergence of new goods implies that the use of old goods decreases. Old production processes are eliminated in favor of the new ones. Better sources of supply replace less productive ones. This will often lead to the devaluation of existing assets even before they become completely useless.

\footnotetext{
${ }^{1}$ The World's Billionaires is a ranking of the richest people in the world compiled by Forbes. Ever since its first publication in 1987, several names have alternated on the list, showing the changing nature of the wealth. See: https://www.forbes.com/billionaires/.
} 
The development process involves losses. Resistance against change, and thus against development, comes not only from old thinking habits and the established owners of wealth and power, but also from within industries. In this sense, Schumpeter (1911) explains that entrepreneurship is not just a job or a sport or a challenge like many others, but the capitalist mode of heroism.

The emergence of the new means that the old must move aside and this "creative destruction" is a great burden on society. Capitalism creates innovation, but each innovation is also a destruction. The emergence of new markets mean that old markets die. For example, the introduction of steamboats meant the gradual disappearance of sailboats. The very excellence of capitalism as a machine of economic progress brings social problems with it because where there are winners, there are also losers. While in general and in the long run, capitalism makes everyone wealthier, the capitalist process also carries a load of costs. Creative destruction as the essential part of capitalism comes with destabilization and rupture. The capitalist system is restless and confronts the economic actors with a constant assault of changing challenges. Nevertheless, the benefit of innovation finally goes to the consumers and workers in the form of better and cheaper products and higher wages because of increased productivity.

\section{Development}

Different from most of the other school of economics, Austrian Economics holds that entrepreneurs play a crucial role in economic development and growth. In the perspective of the Austrian School of Economics, entrepreneurs fulfill the dual role of dealing with uncertainty and making use of locally dispersed knowledge in their activities.

Economic development occurs not only as creative destruction but also in a fragmented way. Therefore, the entrepreneurial function is not limited to the exceptional entrepreneur who achieves the great economic and technological breakthroughs. The entrepreneurial function lies not only in the hands of the businesses but belongs to all economic agents, including consumers, who make conscious use of information and act accordingly.

In the Austrian model, all economic agents engage in entrepreneurial action, be it as entrepreneurs, capitalists and owners or as employees and consumers. The action of all economic agents is entrepreneurial insofar as they reveal an act of choice, focused on the future, among the different means available in order to follow their own subjective order of preferences. Every individual action aimed to a better situation than the present is the pursuit of an entrepreneurial action. Therefore, it is not the individual who is entrepreneurial, but his action.

Economic progress requires a multitude of entrepreneurs competing with each other in search of a new commercial product and more efficient production devices. No one can know beforehand which products and which devices will be most suitable without regard to the ongoing market test. This makes business activity essentially speculative and experimental.

To fulfill their function, markets serve as an institutionalized laboratory for economic progress. It comes as no surprise that economic growth has historically appeared in combination 
with the emergence of a free enterprise system. Freedom and business competition serve as the foundations for capital accumulation and technological progress ${ }^{2}$.

Central economic planning faces fundamental limits because it is burdened with a veil of deep ignorance. Because there is no certain knowledge of the future, the decision maker in economics needs experimental discovery based on speculation. This is exactly what markets offer. Under the condition of ignorance, the logic of planning itself requires a system of discovery, and the best way of economic discovery is the competitive market process.

Furthermore, a market system is also necessary in order to produce knowledge. In addition to dealing with ignorance, the market system serves as an instrument for generating and making use of business knowledge. This valuable type of economic knowledge is only available in a decentralized manner and limited to the specificity of space and time. This type of knowledge is dispersed and is often generated only for a short period of time and can only be evaluated by the local economics actors (

Such an entrepreneur is an actor who knows how to make use of knowledge that cannot be stored, formalized, or sent in a relevant form to a central authority. This knowledge consists of information whose relevance can only be properly judged by the entrepreneur who is able to turn it into economically useful action through business activity.

If one should sum Schumpeter's development model in a sentence one could say that capitalism means innovation and innovation requires entrepreneurs. Unlike in the past, modern capitalism is characterized by mass-oriented, big-market innovations. If, on the one hand, Michelangelo's construction of a church was also a form of innovation, his work was aimed at a specific group. Similarly, Mozart revolutionized music, but wrote most of his works for the nobility.

With the Industrial Revolution came modern capitalism with a form of production that is directed to the mass market. Under capitalism, the workers work for the workers. Different from the past, when the focus point of production was the taste of the king, the nobility, or the cleric, to succeed in capitalism, one must get the taste of the masses right. Thus, capitalism is a system aimed at satisfying the desires of the great mass of consumers. Schumpeter notes that in capitalism one can only make a profit and become rich by producing for the masses.

Schumpeter (1987, p. 96) notes the distinction between growth and economic development. Growth is to produce more of the same products. Economic development is the launch of new products and of new structures. Development needs the entrepreneur who makes innovations. Economic growth can happen without entrepreneurs, through the activities of administrators and technicians.

In Schumpeter's view, economic development is not linear and does not exist in regular waves, but they are highly irregular and deeply disruptive. Where do these waves come from and what is their character? Schumpeter identifies that the entrepreneur is the main agent, but that a proper socioeconomic and political environment is required for him to thrive.

\footnotetext{
${ }^{2}$ The Doing Business project access and evaluate the regulation environment across 190 economies. The project points that the more competitive and efficient the business environment is, the more developed the economies are. See: https://www.doingbusiness.org/.
} 
There must be a financial market available to provide the funds for the entrepreneur so that he can undertake his venture, there must be a tolerance for high pioneer profits to reward the innovative entrepreneur and to give an incentive to the followers and imitators.

While for Schumpeter human action also applies to the entrepreneur, the Schumpeterian entrepreneur goes beyond the mere process of adaptation and marginal change. Regular human action fits the image of the evenly rotating economy. This is also the case with the statics of classical and neoclassical economics. Entrepreneurial action, on the other hand, stands out and is crucial to Schumpeter's theory of development.

In the Schumpeterian typology, the entrepreneur is a person who has a knack and a willingness to overcome resistance to change, seeking a new way to combine the factors of production. Schumpeter (1987, p. 100-101) distinguishes five cases that cover his concept of "new combinations of the factors of production." These five cases form the dynamics of the capitalist system:

1. Creation of a new good. The production of goods that are not yet familiar to the consumer group or add a new quality to an existing good.

2. Introduction of a new production method that is not yet practically known. This new production method need not be based on a new scientific discovery. The new production method may also exist in a new way to market a product.

3. Development of a new market. The creation of a new market in which the industry in question had not yet been established. This market may or may not have existed in rudimentary form before.

4. Acquire a new source of raw materials or semi-finished products. Here, too, it is irrelevant whether this source existed before and was simply ignored or was deemed inaccessible or had to be created first.

5. Perform a reorganization. This may be the establishment of a monopoly position or the breaking of an existing monopoly.

Due to its destructive nature, innovation faces many obstacles. There are power groups that are afraid of losing their position. Schumpeter argues that the rich classes of the past had little interest in capitalism, because capitalism brings its benefit mainly not to them but to the masses. For example, silk stockings that were once exclusive to royalty, modern capitalism produces them for the workers themselves, that is, for the masses. Capitalism itself is a system where no group can maintain its position. That is why Schumpeter writes that capitalism has many enemies, because apparently established positions are constantly at risk. For this reason, too, Schumpeter concludes that capitalism cannot survive, but that the very success of capitalism will bring its death sentence.

Three general principles apply to the phenomenon of economic development (SCHUMPETER, 1911). The first is that there is really purely economic development, the second is that this development is essentially a disturbance of equilibrium, and the third is that economic 
development is not organic, that the developing economy consists of adjacent but relatively independent partial developments.

The development of an economy occurs in the form of a wave and each of these waves has its own characteristics. The general picture of economic development is not an upward curve that obeys a uniform law, but exists in the form of successive curves, each with its own particular shape. The development mechanism would imply a similarity in these development curves, but in reality, political events and other extra-economic events will disrupt the complete continuity of economic development. Development is not uniform, Schumpeter (1911) explains, although there is a uniform direction of development.

The main difference between the Austrian theory and Schumpeter's theory of development is not the figure of the entrepreneur or the function of profits, but the consequences Schumpeter derives from his entrepreneurial theory of development for the origin, role and process of the business cycle. Schumpeter (1987) does not deny that the monetary policy has an influence on the business cycle, but he argues that efforts to stabilize the economy would also mean impeding economic development.

For the Austrians, the business cycle is an aberration, a departure from the natural path of economic development. Booms and bust are brought about by external intervention, typically by the monetary and fiscal authorities. For the Austrians, in general, monetary policy is to blame for the business cycle and, as a result, proper perception of this cause would eliminate the cycle.

For Schumpeter, by contrast, the business cycle is an inherent factor in capitalist development as such it is inevitable. Its origin is the process of development itself, as the realization of new combinations and the following rearrangement of the structure of the economy. There is no therapy that can hinder the economic and social process that comes with declassifications of firms, stocks, lifestyles, cultural values, and ideals, which complement the higher income economic and social progress for all economic subjects (SCHUMPETER, 1987). There is no way up without a way down, and the alternative of progress is stagnation and decline.

Economic progress comes in waves, which have an almost unrecognizable beginning but are likely to become tsunamis. Who makes these waves happen are the entrepreneurs. The pioneering entrepreneur initiates the wave movement and his followers, imitators, and modifiers produce the massive cycles.

The receding wave, which may appear as recession or depression, is fulfilling the promise of the boom. Depression, or rather a return to normal, means that there are more and better goods available, that production has been successfully reorganized to a higher level of productivity, and that production costs are lower (SCHUMPETER, 1987).

What was once the temporarily excessive profit of the leading pioneer companies become permanently higher incomes for the masses (SCHUMPETER, 1987). The dynamic phase of the economy ends, and the economy moves to a more static phase until the next wave arrives. The system is inherently dynamic, always moving, which means for participants that there is always a challenge. This system is bound to innovate. Each innovation is, side by side to creation, a destruction, in which there are always groups that lose. 
The dynamism within the system will create enemies. Capitalism delivers the wealth in the long run, but in the short run life in capitalism appears like a failure. Schumpeter argues that the class that is alienated from the market process is not the class of workers and proletarians, as Marx has identified, but the intellectuals. They are excluded because they do not produce but make public opinion. Thus, the tone that Schumpeter assumes to predict the future development of capitalism is pessimistic.

\section{Final considerations}

The concept of the entrepreneur is essential to Austrian economists. Entrepreneurial action is responsible for solving incongruities in markets and coordinate the economic interactions on the markets. Despite many critics within the Austrian perspective, mainly regarding the figure of the passive and non-owner entrepreneur, Kirzner has widely influenced entrepreneurship research. In general, however, Austrians provide proper definitions on subjects like speculation, capital and profit that are fundamental to understand market processes.

Similarly, Schumpeter's theory of economic development puts the entrepreneur into the center of the capitalist system. With this contribution, Schumpeter wants to complement classical economics. He regards his dynamic theory as a necessary complement of the statics of the Walrasian approach. Economic development requires a society that tolerates creative destruction and the business cycle. The advance of an innovation comes with a boom (upward wave) and runs out with time (downward wave). Interventions to soften the boom would hinder and possibly abort the successful diffusion of the innovations throughout the economy. Similarly, leaning against the slowdown would postpone the normalization of profits and prevent consumers and workers from benefiting fully from the advantages of innovation on the price, quantity and the quality of goods.

In what one may call his second phase, Schumpeter (1942) has disregarded the individual entrepreneur as the main innovator in the future of capitalism. In contrast, these tasks would be embodied in big companies that invest heavily in research and development in order to maintain a stream of innovations. Nevertheless, the great breakthroughs still depend on the individual entrepreneur. Schumpeter's considerations of innovations in his second phase have proved to be only partially true. Even though big companies have invested great sums in research and development programs, the individual entrepreneur has not disappeared. Actually, one can still observe the role of prominent entrepreneurs who dedicate their lives to ideas and become creators of new markets and new products and services.

These considerations form the basis of Schumpeter's pessimism about the future of capitalism. As he realized, the sociopolitical tolerance of high profits which a corporation earns as a consequence of the monopoly position that comes with large-scale innovations is on the decline in the modern society that leans towards a welfare-state. The voters demand security and stability. The majority of the people want protection against disruption. This way, social resistance has become the largest obstacle against innovation. Intellectuals lead the assault against business and the anti-capitalist mentality becomes the dominant social ideology. Schumpeter fears that the age of the entrepreneur is coming to an end and scientific management will take its place. 
Schumpeter's fears were confirmed after the publication of the first edition of his "Theory of Economic Development". World War I saw the rise of the war economy when the entire economic system was subjected to central planning. This experience strengthened Lenin's conviction that central planning is superior to a market economy. The Russian Revolution, the chaos of the interwar years, the Great Depression, and finally World War II, seemed to fully confirm Schumpeter's dark outlook. Different from Schumpeter's dismal view, however, the Western world has experienced a different era since the end of World War II. The market economy returned with a vengeance and triumphed in North America, Western Europe, and in parts of Asia.

Schumpeter's contribution teaches that capitalism continues to develop, against the attitude of the masses and their political representatives. Much of this also goes against the pillars of modern economic theory, which argues that monopolies are bad, excessive profits must be taxed, and the business cycle must be controlled. While these groups, including mainstream economists, maintain macroeconomic targets for growth and inflation, they do not recognize that these targets do not match well with the other set of goals, such as income equality and the multiplicity of economic regulations.

Anti-capitalism feeds on itself. Once its first victories are won and the economy consequently begins to stall, the recession serves as an indicator that the enemies of capitalism are right in their diagnosis that capitalism does not work. This thesis ignores that it was anti-capitalism that caused the failures of the economy. It is not capitalism that brings down the economy, but the struggle against it. Both, the Austrian theory and Schumpeter, beyond their differences, teach the same basic lesson that economic progress which in the end benefits all calls for a free economic order that gives space to entrepreneurial activity and tolerates the temporary emergence of exorbitant profits.

\section{References}

BÖHM-BAWERK, Eugen von. Kapital und Kapitalzins. Innsbruck: Wagner'schen Universitäts-Buchhandlung, 1884.

BOSTAPH, Samuel. Driving the Market Process: "Alertness" Versus Innovation and "Creative Destruction". Quarterly Journal of Austrian Economics, v. 16, n. 4, Winter, 2013.

BUCHANAN, James. Cost and Choice: An Inquiry in Economic Theory. Chicago: Markham Publishing Company, 1969.

FELIPE, Ednilson Silva. Schumpeter, os Neoschumpeterianos e as Instituições: o conceito e o papel numa economia dinâmica e globalizada. In: XII Congresso Brasileiro de História Econômica \& 13 a Conferência Internacional de História de Empresas. Niterói, 2017.

GIANTURCO, Adriano. O empreendedorismo de Israel Kirzner. São Paulo: Instituto Ludwig von Mises. Brasil, 2014.

HAYEK, Friedrich von. Der Wettbewerb als Entdeckungsverfahren. Kieler Vorträge, Neue Folge 56, 1968.

HAYEK, Friedrich von. Economics and Knowledge. Economica, v. 4, New Series, 1937. 
HAYEK, Friedrich von. The Use of Knowledge in Society. American Economic Review, v. 35, n.4. September, p. 519-530, 1945.

HOPPE, Hans-Hermann. A Ciência Econômica e o Método Austríaco. São Paulo: Instituto Ludwig von Mises Brasil, 2010.

IORIO, Ubiratan Jorge. Ação, tempo e conhecimento: A Escola Austríaca de economia. São Paulo: Instituto Ludwig von Mises. Brasil, 2011.

KLEIN, Peter G. A Note on "Human Capital". Published by Mises Wire on June 5, 2014. Available at: https:// mises.org/wire/note-human-capital. Accessed on: Sep 42019.

KLEIN, Peter G. Opportunity discovery, entrepreneurial action, and economic organization. Strategic Entrepreneurship Journal, v. 2, n. 3, p. 175-190, 2008.

KLEIN, Peter G.; BYLUND, Per. The place of Austrian economics in contemporary entrepreneurship research. The Review of Austrian Economics, february, 2014

KNIGHT, Frank. Risk, Uncertainty and Profit. Londres: Houghton Mifflin, 1921.

KIRZNER, Israel. Competition and Entrepreneurship. Chicago: University of Chicago Press, 1973.

KIRZNER, Israel. Creativity and/or Alertness: A Reconsideration of the Schumpeterian Entrepreneur. Review of Austrian Economics, v. 11, p. 5-17, 1999.

KIRZNER, Israel. The Alert and Creative Entrepreneur: A Clarification. Small Business Economics, v. 32, p. 145-52, 2009.

KIRZNER, Israel. The Meaning of the Market Process: Essays in the Development of Modern Austrian Economics. New York: Routledge, 1992.

LACHMANN, Ludwig. Capital and Its Structure. San Francisco: Institute for Human Studies and Cato Institute, 1978.

LACHMANN, Ludwig. Capital, Expectations and the Market Process. Menlo Park: Institute for Humane Studies, 1977.

LACHMANN, Ludwig. The Market as an Economic Process. New York: Basil Blackwell, 1986.

LACHMANN, Ludwig. The Structure of Capital. Kansas City: Sheed, Andrews and McMeel, 1956.

MARX, Karl. O Capital. Crítica da Economia Política. São Paulo: Nova Cultural, 1996.

MENGER, Carl. Principles of Economics. New York: New York University Press, 1985.

MISES, Ludwig von. Human Action. A Treatise on Economics. Auburn, AL: The Mises Institute, 1998.

MISES, Ludwig von. Memoirs. Auburn: Ludwig von Mises Institute, 2009.

MISES, Ludwig von. O cálculo econômico sob o socialismo. São Paulo: Instituto Ludwig von Mises Brasil, 2012.

MISES, Ludwig von. Profit and Loss. In: MISES, Ludwig von (ed). Planning for Freedom. South Holland: Libertarian Press, 1952.

O'DRISCOLL, Gerald P.; RIZZO, Mario J. The Economics of Time and Ignorance. London and New York: Routledge, 1985. 
OPPENHEIMER, Franz. The State: Its History and Development Viewed Sociologically. New York: B. W. Huebsch, 1922.

ROTHBARD, Murray. Economic Thought Before Adam Smith: An Austrian Perspective on the History of Economic Thought. Auburn: Edward Elgar Publishing Ltd, 2006.

ROTHBARD, Murray. Man, Economy, and State: A Treatise on Economic Principles. New York: D. Van Nostrand, 1962.

ROTHBARD, Murray. Power \& Market: Government and the Economy. Menlo Park, California: Institute for Humane Studies. 1970.

SALERNO, Joseph T. Mises and Hayek Dehomogenized. The Review of Austrian Economics, v. 6, n. 2, p. 113-46, 1993.

SALERNO, Joseph T. The Entrepreneur: Real annd Imagined. Quarterly Journal of Austrian Economics, v. 11, p. 188-207, 2008.

SAMUELSON, Paul. Economic Forecasting and Science. Michigan Quarterly Review, v. 4, n. 4. October, p. 274-280, 1965.

SCHUMPETER, Joseph. Business Cycles: A Theoretical, Historical, and Statistical Analysis of the Capitalist Process. New York: McGraw-Hill, 1939.

SCHUMPETER, Joseph. Capitalism, Socialism and Democracy. Nova York: Harper \& Brothers, 1942.

SCHUMPETER, Joseph. Theorie der wirtschaftlichen Entwicklung. Eine Untersuchung über Unternehmergewinn, Kapital, Kredit, Zins und den Konjunkturzyklus. Leipzig: Duncker \& Humblot, 1911.

SCHUMPETER, Joseph. Reimpressão inalterada da 4ª edição publicada em 1934. Berlin: Duncker \& Humblot, 1987.

SHACKLE, G. L. Probability And Uncertainty. Metroeconomica, v 1, p. 161-173, 1949.

SHANE, Scott. A General Theory of Entrepreneurship: the Individual-Opportunity Nexus. Cheltenham: Edward Elgar, 2003.

SMITH, Adam. An Inquiry into the Nature and Causes of the Wealth of Nations. Lausanne: MetaLibri Digital Library, 2007.

SOTO, Jesus Huerta de. A Escola Austríaca. São Paulo: Instituto Mises Brasil, 2010.

WEBER, Max. The Methodology of the Social Sciences. GlencoeThe Free Press, 1949.

RECEBIDO EM: JUL 152019

APRoVAdo EM: SEP 102019 